\title{
My brief but spectacular career in hockey: A life lesson
}

\author{
Robert Bortolussi, MD, FRCPC, CAHS \\ Department of Pediatrics, Faculty of Medicine, Dalhousie University, Halifax, NS
}

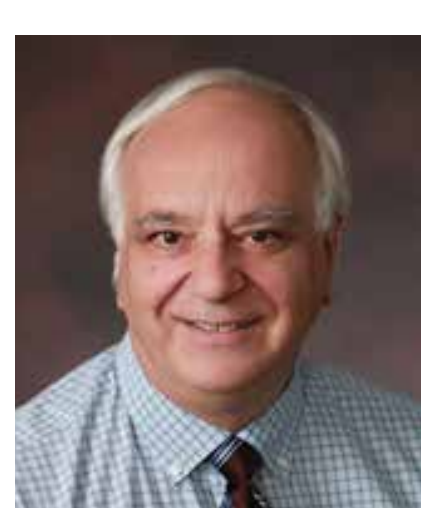

\begin{abstract}
$\mathrm{BIO}$
Bob is a pediatric infectious disease specialist at Dalhousie University, where he did research on the ontogeny of the immune system in neonates. He was VP Research at the IWK Health Centre (1992-2007). He developed the curriculum for a CIHR training program and edited "Handbook for Clinician Scientists". In 2008, he cofounded MicroResearch, which helps clinicians in Africa do research that will improve health programs there. He is also a Professor Emeritus at Dalhousie University and current Editor-in-Chief of CIM.
\end{abstract}

W hen I was 13 years old, there was only one thing I knew with certainty: I would become a professional hockey player. Aside from that, my dreams were modest; play in the National Hockey League $(\mathrm{NHL})$, win a few Stanley Cups and score the winning goal for Canada against the Russians. And so I practiced every day after school on the frozen pond nearby and on weekends from noon until my bedtime. My effort seemed to be paying off. I became the best player on the pond, even better than kids who were older than me!

But the NHL scouts didn't visit the pond where I played. I needed a plan to make my dream a reality. In those days, the Toronto Maple Leafs brought the best players in their farm system to a Toronto high school, St Michael's College School. The school had produced numerous super stars, including Tim Horton, Davie Keon and, my hero, Frank Mahovolich. My parents were delighted, if a bit surprised, when I told them I wanted to go there. In addition to an excellent sports program, St. Mike's also had high academic standards for students; much higher than my grades at my current school. But with hockey as my motivation, my grades improved dramatically, and I was accepted to the school on academic merit. Once this hurdle was overcome, my career progression seemed simple; make the $B$ team, and then the A team, and then gain the notice of the hockey scouts who were hunting for a top prospect.

At the first opportunity, I tried out for the B team; step one in my master plan. To my surprise, among those trying for the team was Peter Mahovolich; the younger brother of my hockey hero. In his teenage awkwardness, Peter seemed vulnerable and no match for his older brother. I decided to test my skills, grabbed the puck from him and skated toward centre ice. And so, for a few brief seconds, it was as if I was competing against Pete's older brother, the real Mahovolich. My joy ended quickly, as Pete caught up, casually lifted my stick to retrieve the puck and skated away. On that day, I learned that Pete, and everyone else at the try-out, were faster and more skilled than me. My hockey dream ended and I was devastated.

At times like these, when one's plans are exposed as unrealistic dreams, one needs to look for a new direction; to reset one's compass. Fortunately, at that same time, two incredible teachers entered my life; Hugh McDougall and John Egsgard. Mathematics and history became my new obsessions, and nurtured in me a love for science. I ended my hockey-jock lifestyle and became 
a science nerd and was eventually accepted into medical school at the University of Toronto. After four years, I went on to internship and then residency, where my passion for research was born. My first (albeit modified) plan was to practice family medicine. Later, I again modified my plan to become a general pediatrician and, eventually, an infectious disease specialist. Each time, my change in direction was inspired by a role model: a clinician, a teacher or a scientist.

With my wife, Michele, I moved around Canada, the United States and then Europe to train and find opportunities to do research on the origins of the immune system in newborns. Our family expanded to include three sons over these years. Eventually we settled in Halifax, where I did grant-funded basic and clinical research and practiced in the area of pediatric infectious diseases for 37 years. Dalhousie and the IWK Health Centre encouraged my research, and enabled me to meet several incredibly gifted clinicians, scientists and teachers, including some who are leaders in the Canadian Society for Clinical Investigation: Jean Gray, Jason Berman and Noni MacDonald. These clinicians/researchers expanded my horizons and helped me attempt projects that I could not have dreamt of on my own. They also helped me to become a better human being.

With time, I assumed several unplanned roles; research curriculum developer (for a CIHR sponsored Training program), Research Vice President (for the IWK Health Centre) and Journal Editor-in-Chief (for Clinical and Investigative Medicine). When I retired from my academic career, I found a new path to follow: with Noni MacDonald at Dalhousie University and others, we founded the MicroResearch program that trains and mentors clinicians in Africa and Asia to do investigator-initiated, community-based research. We have trained almost 1,000 clinicians and helped to launch approximately 70 research projects. These research projects are already changing practice and improving health for people in Africa.

As my own career evolved, Pete Mahovolich, moved on with his. With good coaching, he made the St. Mike's team and became a star in the Ontario Hockey League. He was drafted by the Detroit Red Wings, but bounced between NHL and minor league teams for four years. He was eventually traded to the Montreal Canadiens, where his older brother Frank played. There, with Frank's mentoring, his career blossomed. He became a star, collected three Stanley Cups and was invited to join the Canadian team in the famous 1972 Canadian-Soviet showdown series. He scored a short-handed, winning goal in game three, without which, Paul Henderson's final game heroics would have meant nothing.

Neither my hockey buddy Pete nor I could have predicted the directions our careers would take. Mine did not progress as I had originally planned. Instead, I was guided by my mentors, but also followed the passion that drove me.

Lessons learned:

- Discover the 'fire in your belly' that drives you, and follow it.

- Be prepared to move in a new direction if circumstances and opportunities change.

- Train at the best centre you can, even if it entails challenge, it will eventually pay off.

- Find the best coaches to learn the skills you need.

- At every turning point in your planned career, seek out a mentor, who has the honesty to tell you what he or she thinks, even if it hurts.

Some people believe in the saying, "When one door closes, a new one opens". In truth, I believe that one door's closing merely opens your eyes to new paths that were there from the beginning.

CORRESPONDENCE TO: E-mail robert.bortolussi@dal.ca 